\title{
PICKETING AND PUBLICITY UNDER SECTION 8(b)(4) OF THE LMRA*
}

IN two recent decisions - NLRB v. Servette, Inc. ${ }^{1}$ and $N L R B$ v. Local 760 , Fruit Packers ${ }^{2}$ - the Supreme Court sought to resolve several of the major problem areas created by the 1959 Landrum-Griffin amendments ${ }^{3}$ to the secondary boycott provisions contained in Section 8(b)(4) of the TaftHartley Act. ${ }^{4}$ These amendments culminated a congressional effort begun in 1947 to prohibit union pressure on employers not directly involved in a labor dispute between the union and the primary employer. In 1947 Congress, believing that unions had abused the power given to them by the Wagner Act of 1935,5 enacted the Taft-Hartley Act as a corrective. One of the prime targets of this legislation was the highly effective secondary boycott. ${ }^{\cdot}$ Such a boycott was used frequently against Employer A, an important customer or supplier of Employer B, the employer with whom the union had its primary dispute. A's employees would be induced to strike until A severed business relations with $B$, thereby forcing $B$ to succumb to the union's demands. Although $A$, the secondary employer, aided $B$, the primary employer, by continuing to deal with him, Congress felt the secondary employer was too remote from the primary labor dispute to justify union pressure against him. ${ }^{7}$ To eliminate such pressure, the Taft-Hartley Act outlawed as an unfair labor

*The Editors of the Journal wish to express their appreciation to Professor Harry H. Wellington for his assistance and for calling to their attention this Note, originally written as a divisional paper in the Labor Division.

1. 377 U.S. 46 (1964).

2. 377 U.S. 58 (1964).

3. Labor-Management Reporting and Disclosure Act of 1959, $\$ 704$ (a), 73 Stat. 54243 (1959), 29 U.S.C. \& 158(b) (4) (Supp. IV, 1963) [hereinafter cited as LMRDA].

4. Labor-Management Relations Act of 1947, $\S 8($ b) (4), 61 Stat. 141-42 (1947) [hereinafter cited as LMRA].

5. National Labor Relations Act of 1935,49 Stat. 449. See, e.g., NLRB v. Local 639 , Drivers Union (Curtis), 362 U.S. 274, 285-90 (1960) ; Local 1976, United Bhd. of Carpenters v. NLRB (Sand Door), 357 U.S. 93, 98-100 (1958).

6. See, e.g., statement by Senator Taft, sponsor of the bill, during debate:

It has been set forth that there are good secondary boycotts and bad secondary boycotts. Our committee heard evidence for weeks and never succeeded in having anyone tell us any difference between different kinds of secondary boycotts. So we have so broadened the provision dealing with secondary boycotts as to make them an unfair labor practice.

93 CoNG. Rec. 4198 (1947).

Senator Taft also noted the provision to be "an extremely important one." 93 Covg. REc. 3838 (1947). See also H.R. REP. No. 510, 80th Cong., 1st Sess. 43 (1947) ; Mulroy, The Taft-Hartley Act in Action, 15 U. CHr. L. REv. 595, 596 (1948).

7. See, e.g., remarks of Senator Taft, 93 Cong. Rec. 3838 (1947); 93 Cong. Rec. 4198 (1947); Senator Ellender, 93 CoNG. REc. 4131-32 (1947). 
practice union activity consisting of two elements: where the union by its conduct did

engage in, or ... induce or encourage the employees of any employer to engage in, a strike or a concerted refusal in the course of their employment to use, manufacture, process, transport, or otherwise handle or work on any goods, articles, materials, or commodities or to perform any services...8

and where an object of such conduct was

forcing or requiring . . . any employer or other person to cease using, selling, handling, transporting, or otherwise dealing in the products of any other producer, processor, or manufacturer, or to cease doing business with any other person ....9

Soon, however, unions found new methods of accomplishing the prohibited "object" without running afoul of the "conduct" proscription. One such method was to bring pressure directly against the secondary employer; for example, by use of an overt threat or consumer picketing, while at the same time insuring that none of his employees would be unlawfully induced.10 Another method was to direct activity toward individuals who did not fall within the statutory definition of "employees" of any "employer."11

It was in part the desire to outlaw these methods of evasion which prompted Congress to include amendments of the secondary boycott provisions of the Taft-Hartley Act in the 1959 Landrum-Griffin Bill. ${ }^{12}$ The conduct portion of Section 8(b) (4), now divided into two clauses, continued to prohibit inducement and encouragement in the new subsection (i), but substituted "any individual employed by any person" for "the employees of any employer." A new subsection (ii) was added prohibiting conduct which would "threaten, coerce,

8. LMRA \& 8(b) (4).

9. LMRA \& 8(b) (4) (A).

10. See, e.g., Local 1976, United Bhd. of Carpenters v. NLRB (Sand Door), 357 U.S. 93 (1958); NLRB v. Business Mach. Mechanics Bd., 228 F.2d 553 (2d Cir. 1955), cert. denied, 351 U.S. 962 (1956) ; Rabouin v. NLRB, 195 F.2d 906, 911-12 (2d Cir. 1952); Aaron, The Labor-Management Reporting and Disclosure Act of 1959, 73 HARv. L. REv. 1086, 1113 (1960).

11. In determining whether the inducement of "employees of any employer" violated $\$ 8(b)(4)$, the Board looked to the statutory definitions of "employee" and "employer" and excluded the conduct from the prohibition of the act if either the secondary employer or his employees were not covered by the definition. Thus "employer" does not include federal or state governments or subdivisions and agencies thereof, non-profit hospitals, or persons subject to the Railway Labor Act. LMRA § 2(2). "Employee" excludes supervisors, agricultural workers, and workers employed by an employer subject to the Railway Labor Act. LMRA § 2(3). A union could, therefore, apply otherwise unlawful pressure against these several classes of employees. See Note, The Landrum-Griffin Amendments: Labor's Use of the Secondary Boycott, 45 CoRNELL L.Q. 724, 736-37 (1960) and cases cited therein; Aaron, supra note 10.

12. See analysis by Representative Griffin, 105 CoNG. REC. 14347 (1959), reprinted in 2 NLRB, Legislative History of the LaboR-Managengent Reporting and DisCLOSURE ACT of 1959, 1522-23 (1959) [hereinafter cited as LEGIS. Hist.] ; remarks by Representative Rhodes, 105 Cong. Rec. $15544-45$ (1959), 2 Legrs. Hisr. 1581 (1959); remarks by Senator Goldwater, 105 CoNg. Rec. 19771 (1959), 2 LEgrs. HIST. 1857 (1959). 
or restrain any person ;" thus, conduct directed toward anyone outside the scope of (i) might still be subject to the prohibition of (ii)..$^{13}$ In addition, Congress attached a proviso exempting "publicity, other than picketing" from the restrictions of subsections (i) and (ii). ${ }^{14}$ These new provisions - inartistically drawn and a product of compromise ${ }^{15}$ - have given rise during their five year history to several problems with respect to permissible union conduct and have led, in turn, to considerable litigation with resultant conflicts in the decisions of various courts and the National Labor Relations Board. While Servette and Fruit Packers were the first Supreme Court cases dealing with these amendments, neither case fully resolved the problems presented by the amendments, ${ }^{16}$ and Fruit Packers seems to have created more problems than it resolved.

13. Subsection (ii) of 8 (b) (4) applies to "any person." Section 2 of the act defines person to include "one or more individuals, labor organizations, partnerships, associations, corporations, legal representatives, trustees, trustees in bankruptcy, or receivers." IMRA $\S 2(1)$. Under subsection (i) of $8(\mathrm{~b})(4)$, however, the "individual" must be "employed by any person." Although everyone who is an "individual" under (i) will of necessity also be a "person" under (ii), a union's conduct may violate (i) without violating (ii); for while an inducement is sufficient for a violation of (i), any pressure short of a threat, coercion, or restraint is permissible under (ii). For an example of the slight amount of pressure required to constitute an inducement, see Local 294, Sheet Metal Workers (S.M. Kisner), 131 N.L.R.B. 1196 (1961), where a violation of (i) was found when a union representative told an "individual" that the union "wished" that a contract would not be awarded to a certain employer.

14. LMRDA \& 704(a), 73 Stat. 542-43 (1959), 29 U.S.C. § 158(b) (4) (Supp. IV, 1963). By its terms the proviso exempts conduct constituting "publicity, other than picketing, for the purpose of truthfully advising the public [of a] primary dispute" from both (i) and (ii). See text at note 32 infra. In reality, however, it does not seem to afford exemption for such publicity as induces or encourages within the scope of subsection (i), for the proviso is limited by a phrase couched in words almost identical to the language of (i):

... as long as such publicity does not have an effect of inducing any individual employed by any person other than the primary employer in the course of his employment to refuse to pick up, deliver, or transport any goods, or not to perform any services, at the establishment of the employer engaged in such distribution.... Any conduct violating (i) would seem to fall within this phrase and therefore be outside the proviso's exemption.

15. See Aaron, The Labor-Management Reporting and Disclosure Act of 1959, 73 Harv. L. Rev. 1086, 1114 (1960); Cox, The Landrum-Griffin Amendments to the National Labor Relations Act, 44 MINN. L. REv. 257, 273-74 (1959). Cf. Senator Kennedy's remarks, 105 CoNg. Rec. 17898-99 (1959), 2 LEGrs. HIst. 1432 (1959).

16. E.g., where is the line drawn between "threaten, coerce, or restrain" in subsection (ii) and lesser forms of persuasion? See, Local 901, Teamsters Union v. Compton, 291 F.2d 793, 797 (1st Cir. 1961). Does consumer picketing per se violate subsection (i)? Compare Local 61, Upholsterers Workers (Minneapolis House Furnishing), 132 N.L.R.B. 40, 43-44 (1961), with Burr \& Perfection Mattress \& Spring Co. v. NLRB, 321 F.2d 612, 617-22 (5th Cir. 1963). May a union use force prohibited by (i) or (ii) to obtain or enforce a hot cargo agreement made legal by the construction industry exemption to the general prohibition contained in $\S 8(\mathrm{e})$ of the amended IMRA? Is such an agreement enforceable in court? See, Local 383, Construction Laborers v. NLRB, 323 F.2d 422 (9th Cir. 1963); Note, 39 Notre DaAIE LAw. 220 (1964). 
In Servette a distributor of specialty food merchandise filed a complaint with the NLRB alleging in part that the union had violated subsection (i) of Section 8(b) (4) by inducing and encouraging managers of supermarkets to cease handling Servette's merchandise. The Board, rejecting this allegation, found the supermarket managers not to be "individuals" within the scope of (i) ${ }^{17}$ The Board based this finding on its holdings in two previous decisions, ${ }^{18}$ in which it had reasoned that an interpretation of the phrase "individual employed by any person" to include everyone employed by another would render (ii) largely insignificant. ${ }^{19}$ The Board felt such a view should not be ascribed to Congress without convincing evidence of an intended broad scope for (i), and the Board discovered no legislative history indicating that Congress had, in fact, meant (i) to have such wide application. On the contrary, the Board found evidence that the purpose of substituting "individual" for "employee" in subsection (i) was to avoid the problems created by the Taft-Hartley definition of employee and to include within the "inducement" prohibition lower echelon supervisory personnel, thought to be readily subject to union pressure. $^{20}$ Thus the Board in Servette placed only those employees exercising no managerial discretion or those who by work, association or interest are closely aligned with the rank-and-file within the statutory category of "individual" created by subsection (i) ${ }^{21}$

Although not clearly articulated by the Board, this rationale seems consistent with another major congressional purpose represented by (i) - preventing the disruption of the secondary employer's business. ${ }^{22}$ "Individual" as interpreted by the Board seems to include only those most likely to cause

17. Local 848, Wholesale Delivery Drivers Union (Servette, Inc.), 133 N.L.R.B. 1501 (1961).

18. Local 505, Teamsters Union (Carolina Lumber Co.), 130 N.L.R.B. 1438, 1444 (1961) ; Local 61, Upholsterers Workers (Minneapolis House Furnishing), 132 N.L.R.B. 40, 43 (1961).

19. Since even corporate officers would be employed by a "person," see note 13 supra, thereby falling within (i), only a partner or proprietor of a business would be included within (ii) and not (i). Thus unless "refusal . . . to perform any services" in (i) is read so as not to include the exercise of discretion, any threat under (ii) directed toward a corporate officer would necessarily also constitute an unlawful inducement under (i). This interpretation of "perform any services" was given by the Supreme Court in Servette, reversing the Ninth Circuit's contrary reasoning. See text at and following note 46 infra.

20. See, e.g., the analysis by Representative Thompson and Senator Kennedy, 105 CoNG. Rec. 16589 (1959), 2 LEgrs. Hrst. 1707 (1959), and remarks by Senator Morse, 105 CoNG. Rec. 17882-83 (1959), 2 Legrs. Hrst. 1426 (1959).

21. 133 N.L.R.B. at 1501-02.

22. The language of subsection (i) prohibits inducement or encouragement of "a strike or a refusal ... to use, manufacture, process, transport, or otherwise handle or work on any goods, articles, materials, or commodities or to perform any services ..." All of these activities relate to a disruption at the secondary site, although the general purpose of the entire $\$ 8(\mathrm{~b})(4)$ (i), (ii) (B) is to preserve the business relationship between the primary and secondary employers. 
such a disruption, should they comply with union wishes. Action by higher ranking supervisory employees would have a less disruptive effect; even if these employees complied with union demands, their ability to exercise choice among competing suppliers or products would enable them to continue to perform their normal services. For example, the managers in Servette had purchasing discretion, and they could easily have bought other distributors' products without disrupting their employer's business, much the same as can a proprietor who unquestionably is not an "individual" within the scope of (i). ${ }^{23}$

Although the Board's interpretation was a reasonable adaptation of congressional intent, it was rejected on appeal by the Ninth Circuit. ${ }^{24}$ The court held that an "individual" under subsection (i) included everyone employed by another. This conclusion was based on the literal language of (i) and was supported by the feeling that a narrower reading would place unions in the untenable position of having to determine whether an employee was within or without the scope of (i) before inducing or encouraging him. ${ }^{25}$ This rationale, however, appears inadequate. While it is true that a narrower reading of (i) would introduce uncertainty with respect to which employees are "individuals," it would seem that any union would be willing to assume this risk in return for the greater freedom of action it would gain in being permitted to apply all pressure short of threats, coercion, and restraint to more people.

The Supreme Court on certiorari attempted to reconcile this felt need for certainty with the manifest legislative intent to restrict the scope of subsection (i) by holding that although everyone employed by another is an "individual," the union,

in asking the managers not to handle Servette items, was not attempting to induce or encourage them to cease performing their managerial duties in order to force their employers to cease doing business with Servette. Rather, the managers were asked to make a managerial decision which the Board found was within their authority to make. ${ }^{26}$

The Court's approach to the interpretation of (i) includes all employees within the scope of the subsection but concentrates on whether an inducement to withhold services has in fact occurred; in contrast the Board's interpretation concentrates on the scope and definition of "individual employed by any person." While the interpretation of the Board and the Court differ, the results reached will normally coincide, as was the case in Servette. However, cases may arise in which the interpretations will lead to conflicting results. Thus while a shipping clerk may have authority to decide which carrier to use, his lower echelon status, his salary, and his closeness to the rank-and-file, would,

23. An "individual" must be "employed by any person" under subsection (i).

24. Servette, Inc. v. NLRB, 310 F.2d 659 (9th Cir. 1962).

25. Id. at 665-67.

26. 377 U.S. at $50-51$. 
under the Board's interpretation, make his inducement a violation of (i).$^{27}$ Under the Supreme Court's interpretation, on the other hand, his discretion alone would apparently require a finding that (i) had not been violated. ${ }^{28}$ Since Congress was in part concerned with restricting the union's power to persuade or dominate lower rank supervisors, who are often present or former union members and therefore readily susceptible to union pressure and discipline, the Board's view seems more consistent with legislative intent. ${ }^{29} \mathrm{How}-$ ever, the term "managerial discretion," left undefined by the Court in its subsection (i) interpretation, may be read as including a consideration of the remuneration, function, responsibility and hierarchical status of the individual involved, as well as his authority to make independent decisions. In order to fully effectuate congressional intent while remaining faithful to the holding of the Supreme Court, the Board in the future might seize upon these definitional possibilities and take a broad view of the term "managerial discretion."

The Court, in addition to deciding the inducement issue under subsection (i), also dealt with the second question raised by Servette's complaint - that the union's distribution of handbills to supermarket customers asking them not to purchase Servette products constituted a threat, coercion, or restraint of the handbilled employer in violation of subsection (ii) of Section $8(\mathrm{~b})(4)$.

27. Local 294, Teamsters Union (Van Transport Lines), 131 N.L.R.B. 242 (1961).

The Board, when it first determined the scope of subsection (i), stated that no single factor would determine the category in which one belongs, but it did enumerate those factors it would consider most important:

(1) The organizational set-up of the employer.

(2) The authority, responsibility, and background of the supervisor involved.

(3) The supervisor's working conditions, duties, and functions on the job involved.

(4) The salary, earnings, perquisites, and benefits received by the supervisor.

Local 505, Teamsters Union (Carolina Lumber Co.), 130 N.L.R.B. 1438, 1444 (1961). 。

In applying the guidelines to specific situations, the Board and courts have found the following are not "individuals" and therefore are beyond the scope of (i) : an officer of a corporation or a partner of a partnership, NLRB v. Local 294, Teamsters Union, 298 F.2d 105 (2d Cir. 1961), affirming and enforcing Van Transport Lines, supra, and Local 299, Sheet Metal Workers (S.M. Kisner), 131 N.L.R.B. 1196 (1961); the manager of a large corporation's only outlet in the particular area, Local 901, Teamsters Union (Editorial "El Imparcial," Inc.), 134 N.L.R.B. 895 (1961) ; job supervisors or superintendents who are top management representatives and who have discretionary authority over subcontractors, Alpert v. Local 379, Teamsters Union, 184 F. Supp. 558 (D. Mass. 1960); S.M. Kisner, supra; Local 324, Operating Engineers (Brewer's City Coal Dock), 131 N.L.R.B. 228 (1961) ; and sales and retail store managers, Local 61, Upholsterers Workers (Minneapolis House Furnishing), 132 N.L.R.B. 40 (1961); Local 848, Wholesale Delivery Drivers (Servette, Inc.), 133 N.L.R.B. 1501 (1961). On the other hand an estimator with limited authority in taking jobs off prints and in placing employees on jobs, S.M. Kisner, supra, and a foreman in charge of routing trucks, NLRB v. Local 294, Teamsters Union, supra (Board and court), were held to be "individuals" within the meaning of $\$ 8(\mathrm{~b})(4)$ (i).

28. See, e.g., discussion at note 26 supra.

29. See authorities cited in note 20 supra. In addition, this view seems consistent with purpose manifest in the structure of subsection (i) - to minimize disruption of the secondary employer's business. See notes 22 and 23 supra and accompanying text. 
Although the Board assumed that the handbilling did in fact threaten, coerce, or restrain, it found no violation of 8 (b) (4), reasoning that under the publicity proviso such conduct was exempt from the proscriptions of the section..$^{30}$ The publicity proviso ${ }^{31}$ states that:

nothing contained in $[\S 8(\mathrm{~b})(4)]$ shall be construed to prohibit publicity, other than picketing, for the purpose of truthfully advising the public, including consumers and members of a labor organization, that a product or products are produced by an employer with whom the labor organization has a primary dispute and are distributed by another employer. ....$^{32}$

The Ninth Circuit, however, found the publicity proviso of no help to the union, since it interpreted the phrase "products . . . produced" to refer to fabricated articles only and thus held that the proviso did not protect Servette,

30. Local 848, Wholesale Delivery Drivers (Servette, Inc.), 133 N.L.R.B. 1501, 1502 (1961), basing its decision on Local 537, Teamsters Union (Lohman Sales Co.), 132 N.L.R.B. 901 (1961).

31. LMRDA § 704(a), 73 Stat. $542-43$ (1959), 29 U.S.C. \& 158(b) (4) (Supp. IV, 1963).

32. 73 Stat. 542-43 (1959), 29 U.S.C. § 158(b) (4) (ii) (Supp. IV, 1963) (emphasis added). This proviso did not originally appear in either the House or the Senate bill; rather, it first appeared in the bill which emerged from the conference and which Congress finally enacted. The Senate conferees feared that the House version, containing clause (ii) but no proviso, would be construed to outlaw all forms of consumer publicity and boycotts. The House conferees had meant clause (ii) only to protect secondary employers from direct union pressure, apparently not realizing its potential broad effect. They were willing to protect limited publicity and consumer boycotts as long as picketing was not included within the proviso's protection. Therefore the proviso was born. See Aaron, The Labor-Management Reporting and Disclosure Act of 1959, 73 HaRv. L. REv. 1086, 1114 (1960) ; Note, The Landrum-Griffin Amendments: Labor's Use of the Secondary Boycott, 45 CoNn. L.Q. 724, 731, 759; compare Senator Kennedy's remarks, 105 CoNG. REC. $17898-99$ (1959), 2 Legrs. Hrst. 1432 (1959). Professor Archibald Cox, who participated in the drafting of the final version of the act, explained the existence of the proviso in this manner:

There is some reason to think that originally the Republicans and Southern Democrats among the House conferees failed to realize that the words [of clause (ii)] were broad enough to reach consumer boycotts and would have agreed to eliminate the prohibition, but President Eisenhower's radio and television appearance placed them in a dilemma. The speech contained an example of secondary picketing which had either to be read as an inducement of employees to engage in a secondary strike, in which case the President has displayed ignorance by demanding that Congress outlaw conduct which had been unlawful for twelve years, or as a demand for a law against picketing which caused a secondary consumer boycott. The sponsors of the Landrum-Griffin bill stood immovably upon the second alternative. The Senate conferees, therefore, sought to narrow the restriction to the exact illustration used by the President. This is the reason for the proviso, which permits ... every other form of publicity except picketing. ... I suspect that the distinction between signal and publicity picketing [in $\$ S(\mathrm{~b})(7)]$ would also have been introduced if it were not for the curious turn of events which made this politically impossible for the sponsors of the Landrum-Griffin amendments.

Cox, The Landrum-Grifin Amendments to the National Labor Relations Act, 44 Mrnn. L. REv. 257, 274 (1959). 
a distributor rather than a fabricator. ${ }^{33}$ But as the Board reasoned, "products ... produced" may also refer in a broader sense to all the results of labor, thereby encompassing the addition of intangible services to a previously fabricated product. ${ }^{34}$ In fact this definition of "products . . . produced" appears most consistent with the purpose of the proviso - to protect union activity "truthfully advising the public ..." - for there is no reason to distinguish advice on product disputes from advice on service disputes. ${ }^{35}$ The legislative debates, moreover, refer to publicity in general, indicating no distinction between objects of publicity to be protected by the proviso. ${ }^{36}$ Basing its holding

33. 310 F.2d 659, 667 (9th Cir. 1962). The court relied on its previous decision in Great Western Broadcasting Co. v. NLRB, 310 F.2d 591 (9th Cir. 1962), in which it held that non-picketing publicity of a primary dispute with a television station was not protected by the proviso.

34. The Board first formulated its basic rationale in Local 537, Teamsters Union (Lohman Sales Co.), 132 N.L.R.B. 901 (1961), where it stated:

Here the issue revolves around the meaning of two words, "product" and "produced." Apparently, our dissenting colleague believes that a "product" can only be a material object and can be "produced" only by one who physically engenders it. The natural meaning of these two words, however, cannot be so limited. Webster's defines "product" as: "Anything produced, as by generation, growth, labor or thought...."

From the foregoing it seems clear that, so far as human effort is concerned, Labor is the prime requisite of one who produces. . . . If our dissenting colleague is right, vast numbers of our working population produce nothing. Their thought, labor, or business enterprise is not a "product." We do not believe that the plain meaning of the words "product" and "produced" requires the Board to draw an uncertain line between those employers engaged essentially or only incidentally in the fabrication of products; between those employers who create a new product or embellish an old one; between products of imagination and those that can be seen, touched, or smelled.

Id., at 906-07.

35. One New York Court of Appeals decision, upholding peaceful product picketing because of a "unity of interest" between the secondary and primary employers, indicated in a dictum that a union could not picket to persuade the public to withdraw patronage generally. Goldfinger v. Feintuch, 276 N.Y. 281, 286, 11 N.E.2d 910, 912 (1937). A later decision, however, upheld the right to picket a store with a burglar alarm serviced by a non-union company, finding the "unity of interest" in the continuing relationship between secondary and primary employer. People v. Muller, 286 N.Y. 281, 36 N.E.2d 206 (1941). The only case in which services picketing would not be allowed is that in which the secondary employer no longer uses the primary employer's services. See People v. Bellows, 281 N.Y. 67, 22 N.E.2d 238 (1939). Thus, as the New York court recognized, a secondary employer is taking sides with and aiding a primary employer by using his services just as much as he would be by purchasing his goods for resale.

36. Thus Senator Kennedy, leader of the Senate conferees and one of the drafters of the proviso, explained the proviso to his colleagues in these terms:

We were not able to persuade the House conferees to permit picketing in front of that secondary shop, but we were able to persuade them to agree that the union shall be free to conduct informational activity short of picketing. In other words, the union can hand out handbills at the shop, can place advertisements in newspapers, can make announcements over the radio, and can carry on all publicity short of having ambulatory picketing in front of a secondary site.

105 CoNG. REc. 17898-99 (1959), 2 LEGIS. HIST. 1432 (1959). Other such remarks: "What was permitted was the giving out of handbills or information through the radio, 
in part on this reasoning, the Supreme Court approved the Board's position in Servette and accepted the broad definition of "products . . produced."37

Another problem present in the publicity proviso, not raised by Servette but analogous to the "products ... produced" question, is the interpretation of the word "distributed." This question is illustrated by a recent case in which the Board under the publicity proviso upheld union activity informing the customers of a supermarket chain that the chain was using the services of a refrigeration company employing non-union plumbers. ${ }^{38}$ In order for the Board to reach this result, it had to assume that the supermarket was distributing the services of the refrigeration company. Although this seems a strained reading of "distributed," it accords with the legislative purpose to enable the public to receive information relevant to labor disputes and is consistent with the Supreme Court's broad interpretation of the proviso in Servette. ${ }^{38}$

Yet another consideration militates toward a liberal interpretation of the publicity proviso and supports the current view of the Board and the Supreme Court regarding "products ... produced . . . and . . . distributed. . . ." A1though the Supreme Court did not consider the issue in Servette, a narrow reading of the publicity proviso would have raised a first amendment question. If publicity concerning a labor dispute involving non-fabricated or nondistributed products were not protected, it would fall within the prohibition of (ii) if it threatened, coerced or restrained an employer. ${ }^{40}$ Publicity may take the form of newspaper, television, or radio advertising, and as such would apparently be an exercise of free speech. Although the Court has not dealt with the constitutional status of advertising related to labor disputes, its recent decision in New York Times $v$. Sullivan, 41 holding a non-commercial newspaper advertisement to be protected by the first amendment, leaves little doubt that such labor advertising would also be within the scope of the first

and so forth." (Senator Kennedy) 105 CoNG. Rec. 17720 (1959), 2 LEgrs. HIst. 1389 (1959). "Hence, the amendments adopted in conference . . . protect the free speech right to appeal to customers by non-picketing methods." (Representative Udall) 105 CoNG. REc. 18135 (1959), 2 LEGIs. Hrst. 1722 (1959). There were some scattered references to "goods" with respect to the publicity proviso, but it appears that the term was used as part of a general example of a consumer boycott. See e.g., remarks of Senator Kennedy, 105 Cong. Rec. 17327 (1959), 2 Legis. Hist. 1377 (1959); remarks of Senator Morse, 105 Cong. Rec. 17882-83 (1959), 2 Legis. Hist. 1426 (1959). In addition, Professor Cox indicated that no distinction was intended. See his statement quoted in note 32 supra.

37. 377 U.S. at 55 .

38. Local 142, Plumbers Union (Shop-Rite Foods, Inc.), 133 N.L.R.B. 307 (1961).

39. Thus the Supreme Court in Servette stated:

The proviso was the outgrowth of a profound Senate concern that the unions' freedom to appeal to the public for support of their case be adequate safeguarded. ... It would fall far short of achieving this basic purpose if the proviso applied only in situations where the union's labor dispute is with the manufacturer or processor.

377 U.S. at 55.

40. See, e.g., Servette, Inc. v. NLRB, 310 F.2d 659 (9th Cir. 1962); Local 537, Teamsters (Lohman Sales Co.), 132 N.L.R.B. 901 (1961).

41. 376 U.S. 254 (1964). 
amendment. ${ }^{42}$ Even if such publicity had the effect proscribed by (ii), it would seem, under established Supreme Court interpretation of the first amendment, to be protected. The Court in Thornhill $v$. Alabama ${ }^{43}$ stated that:

Every expression of opinion on matters that are important has the potentiality of inducing action in the interests of one rather than another group in society. But the group in power ... may not impose penal sanctions on peaceful and truthful discussion of matters of public interest merely on a showing that others may thereby be persuaded to take action inconsistent with its interests. ${ }^{44}$

A narrow construction of the proviso, leaving some publicity subject to possible proscription under (ii) would raise serious constitutional doubts. ${ }^{45}$ However, the Court's broad interpretation of "products . . produced" coupled with the Board's interpretation of "distributed" should avoid this first amendment problem.

Even with the broadly construed proviso, picketing, specifically excepted from its scope, would still be subject to subsection (ii) standards. In Fruit Packers, ${ }^{46}$ the other case decided under Section 8(b) (4), the Supreme Court faced the question whether all picketing by its very nature fell within the proscription of that subsection. The union, in an effort to win a primary labor dispute against fruit packers and warehousemen, picketed a chain of Safeway markets to encourage customers not to buy the primary employers' apples from Safeway. The primary employers filed a complaint with the NLRB charging in part that the union's picketing threatened, coerced, and restrained Safeway in violation of (ii). Although the Board made no finding of an actual threat, coercion, or restraint, it nevertheless held that the union's picketing was a per se violation. ${ }^{47}$ To reach this conclusion, the Board made the ques-

42. In distinguishing Valentine v. Chrestensen, 316 U.S. 52 (1942), which upheld a city ordinance forbidding street distribution of commercial and business advertising matter, the Supreme Court in Sullivan acknowledged "the constitutional protection for "the freedom of communicating information and disseminating opinion" " and stated:

The publication here was not a "commercial" advertisement in the sense in which the word was used in Chrestensen. It communicated information, expressed opinion, recited grievances, protested claimed abuses, and sought financial support on behalf of a movement whose existence and objectives are matters of the highest public interest and concern.

376 U.S. at 266.

43. 310 U.S. 88 (1940).

44. Id. at 104.

45. As the Supreme Court once stated:

[P] ublication, unaccompanied by violence, of a notice that the employer is unfair to organized labor and requesting the public not to patronize him is an exercise of the right of free speech guaranteed by the First Amendment which cannot be made unlawful by act of Congress.

United States v. Hutcheson, 312 U.S. 219, 243 (1941).

46. NLRB v. Local 760, Fruit Packers, 377 U.S. 58 (1964).

47. Local 760, Fruit Packers (Tree Fruits Labor Committee), 132 N.I.R.B. 1172 (1961). The Board was following its holding in prior decisions : Local 261, United Wholesale Employees (Perfection Mattress \& Spring), 129 N.L.R.B. 1014 (1960), affirmed and enforced on this point, 321 F.2d 612 (5th Cir. 1963); Local 61, Upholsterers Union (Minneapolis House Furnishing), 132 N.L.R.B. 40 (1961). 
tionable assumption that Congress, by adding the publicity proviso exempting publicity other than picketing, indicated that all publicity, including picketing, would necessarily have violated (ii). ${ }^{48}$ Relying on past decisions which were supported by quotations from legislative debate, this reasoning led to the conclusion that no finding of fact was necessary to condemn picketing under (ii). ${ }^{49}$ The Court of Appeals for the District of Columbia, agreeing with the Board's reading of congressional intent, nevertheless reasoned that the language of the subsection did not accomplish a per se prohibition of picketing. ${ }^{\text {s0 }}$ According to the court, since (ii) outlawed conduct threatening, coercing, or restraining any person, the subsection could only be read as requiring a factual determination that the conduct in question actually produced those prohibited effects. Consequently the court remanded the case to the Board for a factual finding on the effect of the union's picketing of Safeway. ${ }^{51}$ On appeal the Supreme Court rejected both interpretations of the statute and construed legislative history to support its own holding that picketing at the secondary site, limited to asking consumers not to buy a specific product, did not threaten, coerce, or restrain the secondary employer in violation of (ii) .52

While the distinction drawn by the Court between picketing asking consumers not to buy a specific product and picketing asking them not to trade at all with the secondary employer may not be unreasonable, it lacks support

48. 132 N.L.R.B. at 1172,1177 .

49. Id. at 1177-78. The Board relied on Minneapolis House Furnishing, supra note 47, at 43-44, 62-64; Perfection Mattress \& Spring, supra note 47, at 1022-23.

While various remarks made in Congress indicate that (ii) was thought to prohibit all secondary picketing, none of the legislators addressed himself to the possible existence of picketing which in fact does not threaten, coerce, or restrain the secondary employer. The Board assumed that Congress had faced that possibility and had decided to outlaw even secondary picketing which did not meet the standards of threat, coercion, or restraint. If the publicity proviso were necessary because publicity would otherwise be unlawful under (ii), the only conclusion which follows is that (ii) would have proscribed only such publicity which in fact threatens, coerces, or restrains and that publicity without these (ii) characteristics did not need the added protection of the proviso. By statutory language, no activity which does not constitute a threat, coercion, or restraint can violate (ii). See, e.g., remarks by Senator McClellan, 105 Cong. REc. 6666-67 (1959), 2 LEGIS. HIST. 1193 (1959); remarks by Senator Goldwater, 105 CoNG. REC. 6428 and 17904 (1959), 2 LEGrs. HIrst. 1192, 1437 (1959); remarks by Senator Morse, 105 Cong. REc. 17882-83 (1959), 2 LEgrs. Hisx. 1426-27 (1959); remarks by Senator Kennedy, 105 CONG. REC. 17898-99 (1959), 2 LeGIS. HIST. 1432 (1959); remarks by Representative Griffin, 105 Cong. Rec. 15673 (1959), 2 Legrs. Hist. 1615 (1959); analysis by Representative Thompson and Senator Kennedy, 105 Cong. Rec. 16590-91 (1959), 2 LeGrs. Hrst. 1708 (1959).

50. Local 760, Fruit Packers v. NLRB, 308 F.2d 311 (D.C. Cir. 1962).

Looking solely to the language of the statute, however, we believe the most plausible reading to be that $\$ 8$ (b) (4) (ii) outlaws only such conduct (including picketing) as in fact threatens, coerces, or restrains secondary employers, and that the proviso is intended to exempt from regulation "publicity other than picketing" even though it threatens, coerces, or restrains an employer.

Id. at 315 .

51. Id. at 318 .

52. NLRB v. Local 760, Fruit Packers, 377 U.S. 58 (1964). 
in legislative history. Justice Harlan, in dissent, ${ }^{53}$ established what was also clear to the Board ${ }^{54}$ and the Court of Appeals ${ }^{55}$ - that Congress clearly thought (ii) prohibited all forms of secondary picketing. Even the legislative statements used by the majority do not seem to support its conclusion. The Court, finding particularly significant the fact that product picketing was not specifically mentioned in the debates by the supporters ${ }^{56}$ of the bill, drew the inference that the desire to outlaw picketing evidenced in those debates was inapplicable to product picketing. ${ }^{57}$ Such an inference is justified only if Congress believed the evils flowing from product picketing were significantly less important than those flowing from picketing directed against the entire business of the secondary employer. Otherwise, there would be no reason to read the word "picketing" in the debates and in the statute as not including one form of picketing - that directed to products. In referring to the two types of picketing - product and non-product- the Court makes this same point. "This is not to say that this distinction was expressly alluded to in the debates. It is to say, however, that the consumer picketing carried on in this case (product) is not attended by the abuses at which the statute was directed."58 Yet the Court cites no legislative history evidencing that Congress thought product picketing was not one of the evils to which the statute was directed. Absent such evidence and in light of the repeated use of the unqualified word "picketing" in both the debates and the statute, it would seem that Congress intended no distinction.

The Court, however, derived from "the history of federal regulation of labor relations" a presumption against ascribing to Congress the desire to ban peaceful picketing in the absence of a clear showing that such a ban was intended to eliminate "isolated evil." 59 While this presumption appears to be

53. 377 U.S. at 80 (1964). See also note 49 supra.

54. 132 N.L.R.B. at 1177.

55. $308 \mathrm{~F} .2 \mathrm{~d}$ at 317 .

56. The court took note of statements by Senators Morse and Humphrey which undeniably included product picketing within subsection (ii)'s prohibition, but then stated: "But we have often" cautioned against the danger, when interpreting a statute, of reliance upon the views of its legislative opponents." 377 U.S. at 66.

57. "The silence on the [part of] sponsors of amendments is pregnant with signifcance since they must have been aware that consumer picketing as such had been held to be outside the reach of $\$ \$(b)(4) . " I d$. at 66-67.

58. Id. at 64 .

59. Id. at 62-63. As authority for this presumption, the Court cited NLRB v. Local 639, Drivers Union (Curtis), 362 U.S. 274 (1960). In creating the presumption in Curtis Mr. Justice Brennan, also the author of the Fruit Packers opinion, relied in part upon $\S 13$ of the Taft-Hartley Act, which provides that "Nothing in this subchapter, except as specifically provided for herein, shall be construed so as either to interfere with or impede or diminish in any way the right to strike. . ." 29 U.S.C. $\$ 163$ (1958). The Cutrtis case, however, involved primary, not secondary, picketing - the application of the substantive provisions of the act to minority union picketing for recognition. Viewing picketing as a part of the right to strike, $i d$. at $281 \mathrm{n} .9$, the Court invoked $\S 13$ as:

a rule of construction which cautions against an expansive reading ... which would adversely affect the right to strike, unless the congressional purpose to give it that meaning persuasively appears either from the structure or history of the statute. Therefore, $\S 13$ is a command of Congress to the courts to resolve doubts and 
valid, it is of no help to the Court in reading legislative history to determine the "isolated evils" intended to be eliminated in Section 8 (b) (4). The Court found the evil of peaceful picketing to be its use to persuade customers of the secondary employer to cease all trading with him. ${ }^{60}$ But from the legislative history cited by the Court, it is equally consistent to conclude that the evil sought to be eliminated was the use of all picketing against the secondary employer. ${ }^{61}$ There is, moreover, convincing evidence, not cited by either the majority or the dissent, that an isolated evil of primary concern to Congress was the coercion of the secondary employer. ${ }^{62}$ And as the Court admitted, both product and non-product picketing may have a coercive effect. ${ }^{63}$ Thus even with the presumption, the Court's use of legislative history is unconvincing.

To justify the distinction between product and non-product consumer picketing, the Court forwarded the theory that product picketing is merely an expansion of the primary dispute to a secondary situs through a following of the product," while non-product picketing "creates a separate dispute with the secondary employer."65 Recognizing that this analysis in terms of the remoteness of the picketing from the primary dispute was nowhere mentioned in the legislative history of the section, ${ }^{68}$ the Court imputed this reasoning to

ambiguities in favor of ... the right to strike as understood prior to the passage of the Taft-Hartley Act.

Id. at 282 .

While the use of $\S 13$ to create the presumption might be justified, its use would not seem to be correct in the case of picketing at secondary sites, for it would be directly contrary to congressional efforts in $\$ \$ 8(\mathrm{~b})(4)$ and $8(\mathrm{e})$ (outlawing "hot cargo" agreements) to limit labor disputes to the primary employer's business and to isolate those employers not directly involved. In addition; such a use of $\$ 13$ could have ramifications in the area of common situs picketing. See text accompanying and following note 71 infra. See also note 72 infra. For a criticism of the Court's use of $\S 13$ in the Curtis situation, see Lesnick, The Gravamen of the Secondary Boycott, 62 Colum. L. REv. 1363, 13981403 (1962).

60. 377 U.S. at 63.

61. The Court cites an example of picketing which President Eisenhower gave on a televised speech and which Senator Goldwater said was prohibited by subsection (ii) : a union in a labor dispute with a furniture manufacturer "Instead of picketing the furniture flant itself ... picket[s] the stores which sell the furniture." Id. at $65-66$ n.10.

62. See, e.g., remarks by Senator Goldwater, 105 CoNG. Rec. 1281, 1283 (1959), 2 LegIs. HIsT. 977, 979 (1959) ; remarks by Senator Curtis, 105 CoNG. REC. 1296, 6670 (1959), 2 LEGrs. HIST. 989, 1197 (1959); statement by Secretary of Labor Mitchell, 105 Cong. Rec. 1729-30 (1959), 2 Legrs. HIst. 993-94 (1959); remarks by Senator McClellan, 105 Cong. REC. 6666-67 (1959), 2 LEgis. Hist. 1193 (1959); remarks by Representative Bosch, 105 CoNg. Rec. 1426 (1959), 2 LEGIs. HIST. 1462 (1959) ; remarks by Representative LaFore, 105 CoNg. Rec. 3927-28 (1959), 2 Legrs. Hist. 1470-71 (1959) ; analysis by Representative Griffin, 105 CoNg. REC. 14347 (1959), 2 Legrs. HIST. 1523 (1959).

63. 377 U.S. at 71.

64. "When consumer picketing is employed only to persuade customers not to buy the struck product, the union's appeal is closely confined to the primary dispute." Id. at 72.

65. Ibid.

66. See, e.g., quotation in text at note 58 supra. 
Congress by arguing that the distinction "was well established in the state cases by 1940." 67 Although the Court recognized that this theory of following the product was based primarily on a "unity of interest" between the primary and secondary employer, it failed to recognize, as did later state cases, that the logical extension of the unity of interest concept would also validate some non-product picketing and would destroy the very dichotomy created by the Court in Fruit Packers. Thus the New York Court of Appeals, the author of the leading product picketing case cited by the Court, ${ }^{68}$ reasoned in 1941 that the basis of the unity of interest between the primary and secondary employers was their continuing business relationship; a union, therefore, might picket a store utilizing only services, not products of the primary employer to induce consumers to withdraw all patronage. ${ }^{69}$

The Court's assimilation of product picketing to the primary dispute, however, might be read not as an interpretation of congressional intent, but rather as placing product picketing outside of the scope of 8 (b) (4) entirely. In the past opinions the Court has recognized the all-embracing language of Section 8 (b) (4), and has interpreted the section to apply only to secondary activity; this reasoning is now codified in the proviso to Section 8 (b) (4) (B) exempting primary activity from the scope of the section. ${ }^{70}$ But the expansion of the concept of primary dispute to encompass product picketing may run counter to the rationale of many cases involving common situs picketing. In these cases the courts and the Board, in an effort to balance the effectiveness of union strikes against injury to secondary employers, have permitted primary picketing at secondary or common sites only when no adequate opportunity was available to picket at the primary site. ${ }^{71}$ The interpretation of product picketing as closely related to the primary dispute might therefore be read as eliminating the "no adequate opportunity" restriction and as extending the primary situs doctrines to include the following of products as well as employees. On the other hand, the Court may have meant only to suggest that the concept of primary dispute involved in product picketing was different from the concept

67. 377 U.S. at 64 n.7.

68. Goldfinger v. Feintuch, 276 N.Y. 281, 11 N.E.2d 910 (1937).

69. People v. Muller, 286 N.Y. 281, 36 N.E.2d 206 (1941). See note 35 stpra.

70. LMRDA \& 704(a), 73 Stat. 542-43 (1959), 29 U.S.C. § 8(b)(4)(B) (Supp. IV, 1963). See, e.g., NLRB v. Denver Bldg. Trades Council, 341 U.S. 675, 685-90 (1951); Local 761, IBEW v. NLRB, 366 U.S. 667, 671-72 (1961).

71. See, e.g., Sailors' Union (Moore Dry Dock Co.), 92 N.L.R.B. 547 (1950); Brewery Drivers (Washington Coca-Cola Bottling Works), 107 N.L.R.B. 299, enforced 220 F.2d 380 (D.C. Cir. 1955). These and cases following them "make clear the Board's view that secondary site picketing was lawful only if no adequate opportunity to picket at the primary site were present." Lesnick, The Gravamen of the Secondary Boycott, 62 ColvM. L. Rev. 1362, 1379 (1962).

The rationale of the common situs picketing rules is that the picketing is aimed at the primary employees and that the only meaningful way to get at them is at the secondary site. The countervailing consideration is the factual inference that secondary site picketing is aimed in part at least at the secondary employees. But this inference is invalid if in fact there is no other real way to get to the primary employees. Id. at 1379-80. 
involved in following primary employees to a common situs. Even if the Court's opinion is read only to effect this less radical change in current doctrine concerning the nature of primary activity, this new concept of primary activity was not clearly articulated by the Court; the economic analysis forwarded by the Court appears to be addressed to the problem of "threat, coercion or restraint," although this effect would be immaterial if product picketing were considered to fall within the proviso exempting primary activity and thus beyond the reach of the section. It seems unlikely, moreover, that the Court meant to advance a new doctrine of primary activity by implication without any explicit discussion of the reasoning and ramifications behind its departure. For this reason, it appears that the Court may have seized upon the analysis of the proximity of product picketing to the primary dispute in an effort to support its finding of an isolated evil without considering the full implications of the rationale. ${ }^{22}$

The Court further justified its distinction between product and non-product picketing by analyzing the economic consequences of the two forms of picketing. The Court concluded that successful product picketing would decrease the secondary employer's purchases from the primary employer "only because the public has diminished its purchases of the struck product;"73 a total consumer boycott of the secondary employer would, however, decrease the purchases from the primary employer because of "pressure designed to inflict injury on his business generally."74 Mr. Justice Harlan in dissent demonstrated the disutility of this economic analysis by citing the example of an independent gas station owner who purchases all his gasoline from a struck refinery. ${ }^{75}$ It makes little difference to him or to the union whether the pickets ask the public not to buy the gasoline products he sells, or not to buy anything from him. While asking the public not to buy $\mathrm{X}$ gasoline is technically product picketing, in substance it creates the isolated evil thought by the Court to be prohibited by Congress in the statute - the use of picketing "to persuade the customers of the secondary employer to cease trading with him in order to force him to cease dealing with . . . the primary employer."76 In substance a difficult problem of classification is created. In each instance a court may have to determine whether the product constitutes so substantial a proportion of the secondary employer's business that picketing of that product would be tantamount to asking consumers not to deal at all with the employer.

72. Even if the Court did consider product picketing to be primary in nature, its use of $\$ 13$ of Taft-Hartley from NLRB v. Local 639, Drivers Union (Curtis), 362 U.S. 274 (1960), see note 59 supra, in reading legislative history would be unjustified. In Fruit Packers the Court, if it used $\S 13$, used it to create an ambiguity in the meaning of the word "picketing" in the debate; on the other hand, in Curtis the Court found no clear evidence of congressional intent either to ban or not to ban picketing, because the House version of the Taft-Hartley Act, expressly banning picketing to gain recognition, was not adopted by the Conference Committee. The presumption drawn from $\S 13$ was then applied only after the legislative history had indicated an ambiguity.

73. 377 U.S. at 72.

74. Ibid.

75. Id. at 83 .

76. Id. at 63 . 
The result reached by the Court may, however, be explained as an attempt to avoid the first amendment questions raised by a broad ban on peaceful picketing. ${ }^{77}$ If this was the Court's aim, its decision probably extended more protection to product picketing than would be required by the first amendment. While the Court in the landmark case of Thornbill $v$. Alabama ${ }^{78}$ recognized that "the dissemination of information concerning the facts of a labor dispute must be regarded as within that area of free discussion that is guaranteed by the Constitution,"'79 recent cases have permitted prohibition of peaceful picketing in the pursuit of valid public policies. Justice Black, concurring in Fruit Packers, states these valid policies to be: (1) keeping the streets clear for the movement of people and property, (2) promoting the public safety, peace, comfort, or convenience, and (3) protecting people from violence and breaches of the peace. ${ }^{80} \mathrm{He}$ neglects to state, however, that in a large number of cases upholding bans on picketing the Court considered as a valid public policy the prevention of coercion. These cases would seem to indicate that if picketing actually coerced secondary employers, it could be constitutionally prohibited pursuant to the valid public policy of preventing coercion of secondary employers. If product picketing fell within the standards of (ii) in any given situation, there would then appear to be no constitutional reason to exempt it from prohibition. ${ }^{81}$

On the other hand, the Court's attempt to justify exclusion of product picketing from (ii) on the basis of legislative intent, might create a first amendment question by establishing a per se rule against non-product picketing: "picketing which persuades the customers of a secondary employer to stop all trading with him was . . to be barred." 82 While it is likely that most non-product picketing will in fact "threaten, coerce, or restrain," there might be some instances in which it will not. In such a case, prohibition of the picketing involved would not be pursuant to a valid public policy; rather, as Justice Black stated in his concurring opinion, "the result is an abridgment of the freedom of these picketers to tell a part of the public their side of a labor

77. The Court, after describing its "isolated evils" presumption in interpreting statutes restricting the right to picket stated:

Both the congressional policy and our adherence to this principle of interpretation reflect concern that a broad ban against peaceful picketing might collide with the guarantees of the First Amendment.

377 U.S. at 63.

78. 310 U.S. 88 (1940).

79. Id. at 102 .

80. 377 U.S. at 78 .

81. While the state statutes and common law prohibiting picketing took the form of laws regulating restraint of trade, labor relations, or race relations, the Supreme Court was always careful to note that the picketing involved always contained an element of coercion or compulsion. See, e.g., Giboney v. Empire Storage \& Ice Co., 336 U.S. 490 (1949) ; Hughes v. Superior Court, 339 U.S. 460 (1950); Building Service Employees v. Gazzam, 339 U.S. 532 (1950) ; Local 10, Plumbers Union v. Graham, 345 U.S. 192 (1953) ; Local 695, Teamsters Union v. Vogt, Inc., 354 U.S. 284 (1957).

82. 377 U.S. at 71. 
controversy, a subject the free discussion of which is protected by the First Amendment." 83

The Court, however, might have avoided the first amendment problem by adopting the Court of Appeals' reading of (ii), construing the subsection to prohibit all picketing, product or non-product, which in fact threatened, coerced, or restrained a secondary employer. ${ }^{84}$ This reading of (ii) seems to be within the constitutional line of demarcation established in previous picketing cases; only conduct accomplishing the evil of actual coercion - a valid object of public policy ${ }^{85}$ - would be banned. This interpretation, moreover, would not seem to violate congressional intent. Not only is there evidence that Congress itself considered the primary evil to be the actual coercion of secondary employers, ${ }^{86}$ but the section itself is structured in this way. Since the publicity proviso does not extend to picketing, it merely leaves the status of such conduct to be measured by (ii) standards; subsection (ii) does not ban all picketing, but only that conduct which constitutes a threat, coercion, or restraint. Accepting, however, the Supreme Court's distinction between product and non-product picketing, the Board or a court might still utilize the Court of Appeals' construction of subsection (ii) ${ }^{87}$ to avoid first amendment doubts concerning the ban on non-product picketing. To accomplish this, only that non-product picketing found to actually threaten, coerce, or restrain would be prohibited under subsection (ii).

A final issue present but unrecognized in the Fruit Packers and Servette opinions is the problem of distinguishing between picketing and "publicity, other than picketing." Since non-product picketing is subjected to prohibition under (ii) by the Court's decision in Fruit Packers and since all publicity other than picketing is protected by the proviso under the Servette decision, the distinction between types of publicity becomes important in cases involving non-product publicity. A serious problem of classification may be present with respect to the increasingly popular labor tactic of handbilling. Handbilling typically the stationary distribution of leaflets describing the union's primary dispute at the entrances of the secondary employer's premises - has been used more frequently in recent years to avoid the high cost of mass media advertising and to localize appeal to those most likely to patronize the secondary employer. ${ }^{88}$ While this tactic was employed in Servette, the Court assumed without discussion that it was not picketing. ${ }^{89}$ Although handbilling is similar to

S3. Id. at 79.

84. Local 760, Fruit Packers v. NLRB, 308 F.2d 311 (D.C. Cir. 1962). See discussion at note 50 supra. This is not to say, however, that the Supreme Court should, as the Court of Appeals intimated, have required actual economic harm to the secondary employer before finding a threat, coercion, or restraint. See 377 U.S. at 71-72.

85. See note 81 supra and accompanying text.

86. See note 62 supra.

87. See text at note 50 supra. See also note 84 supra.

88. See, e.g., Waldman, Problems of the Boycott - A Labor Viewooint, N.Y.U. 14тн CoNF. on LAB. 47, 66-67 (1961).

89. NLRB v. Servette, Inc., 377 U.S. 46 (1964). 
picketing, ${ }^{90}$ since both are conducted at or near the secondary employer's premises, the two often differ in several important respects. Handbilling is normally stationary rather than ambulatory. One or more members marching back and forth in front of a store command greater attention and interfere more with passers-by than persons standing still near entrances. Handbilling, moreover, involves small leaflets instead of large placards. The former are less conspicuous and less likely to incite secondary employees to stop work than the latter. And handbilling, like mass media advertising, seems better adapted to "truthfully advising the public" than does picketing. Finally, handbilling was specifically mentioned as a protected activity by Senator Kennedy, leader of the Senate conferees responsible for drafting the proviso.91 In spite of these considerations, there may be instances in which distribution of leaflets should be considered picketing. For example, the distribution may involve persons patrolling the secondary employer's establishment, or large numbers of people distributing leaflets may block entrances and impede entry or exit of employees and customers. ${ }^{92}$ Such activity, if it is non-product and in fact threatens, coerces, or restrains the secondary employer, should be held to violate subsection (ii). Thus, the decision in many cases would seem to depend upon the character of the union activity involved, rather than the label conventionally attached. In distinguishing between picketing and handbilling, the Board or court would be skirting a potential first amendment issue. Picketing has been found subject to regulation under the first amendment because of its speechplus characteristics - its historical connection with industrial strife and its physical aspects such as endangering public safety or obstruction of public traffic. ${ }^{93}$ To avoid the possible first amendment issue, handbilling should be placed within the scope of the publicity proviso except in the case where it clearly partakes of the speech-plus characteristics traditionally associated with picketing.

Dennis G. Seinfeld

90. Two state court decisions have equated handbilling with picketing under state anti-picketing statutes. Mason \& Dixon Lines, Inc. v. Odom, 193 Ga. 471, 18 S.E.2d 841 (1942) ; Kitty Kelly Shoe Corp. v. Local 108, United Retail Employees, 125 N.J. Eq. 250, 5 A.2d 682 (1939). In addition, three federal district courts have held handbilling to constitute prohibited conduct under (ii), but none of the opinions elaborated its reasoning or mentioned the publicity proviso. Shore v. Local 712, International Bhd. of Electrical Workers, 48 L.R.R.M. 2231 (W.D. Pa. 1961) ; Potter v. Local 142, Plumbers Union, 192 F. Supp. 641 (W.D. Tex. 1960) ; Phillips v. Local 662, Radio \& Television Engineers (E.D. Tenn. 1960), unpublished but cited in Potter v. Plant Guard Workers, 47 L.R.R.M. 2804, 2807 (S.D. Tex. 1961).

91. 105 Cong. Rec. 17898-99 (1959), 2 Legrs. Hrst. 1432 (1959). See quotations in note 36 supra.

92. See, e.g., Local 399, Service Employees (Burns Detective Agency), 136 N.L.R.B. 431 (1962).

93. See Fruit Packers, 377 U.S. 58, 78 (1964) (Black, J., concurring); Local 802, Teamsters Union v. Wohl, 315 U.S. 769, 775 (1942) (Douglas, J., concurring). See also Local 695, Teamsters Union v. Vogt, Inc., 354 U.S. 284, 289 (1957). 